\title{
Milliequivalent per Liter
}

National Cancer Institute

\section{Source}

National Cancer Institute. Milliequivalent per Liter. NCI Thesaurus. Code C67474.

A concentration unit measured as a number of milliequivalents of solute per liter of solution. 